Jenius: Jurnal of Education Policy and Elementary Education Issues

Vol.1, No.2, Desember 2020, pp. 74-82

\title{
IMPLEMENTASI MODEL PEMBELAJARAN NHT MENINGKATKAN HASIL BELAJAR PESERTA DIDIK KELAS III SD
}

\author{
Sumarti \\ SD Negeri Pasarbanggi, Rembang \\ E-mail: sumarti2pasarbanggi@gmail.com
}

\begin{abstract}
The purpose of this study was to improve learning outcomes in Civics subjects material practicing the meaning of the values of the youth oath through the application of the cooperative learning model type NHT (Number Head Together) for Class III students. The research was conducted at SDN 2 Pasarbanggi Rembang in the first semester of the 2018/2019 academic year. This research is Classroom Action Research (CAR). The subjects of this study were 17 students of Class III SDN 2 Pasarbanggi. Data collection techniques with test techniques and non-test techniques. The test technique uses items, while the non-test technique uses observation and documentation. Data collection tools are test questions and observation sheets. Data analysis technique is descriptive analysis technique. The results showed an increase in participants' learning outcomes, namely the average pre-cycle score was $59.4(47 \%)$, the first cycle showed an average of 68.8 (59\%) and the second cycle was 84.1 (88\%). There was an increase in student learning outcomes after the implementation of the NHT learning model by 24.7 (41\%).
\end{abstract}

Keywords: Civics; Learning outcomes; Number Head Together

Abstrak Tujuan penelitian ini adalah meningkatkan hasil belajar pada matapelajaran PKn materi mengamalkan makna nilai-nilai sumpah pemuda melalui penerapan model pembelajaran kooperatif tipe NHT (Number Head Together) peserta didik Kelas III. Penelitian dilakukan di SDN 2 Pasarbanggi Rembang pada Semester I tahun ajaran 2018/2019. Penelitian ini adalah Penelitian Tindakan Kelas (PTK). Subyek penelitian ini adalah 17 peserta didik Kelas III SDN 2 Pasarbanggi. Teknik pengumpulan data dengan teknik tes dan teknik non tes. Teknik tes menggunakan butir soal, sedangkan teknik non tes menggunakan observasi dan dokumentasi. Alat pengumpulan data adalah soal ulangan dan lembar observasi. Teknik analisis data adalah teknik analisis deskriptif. Hasil penelitian menunjukkan adanya peningkatan hasil belajar peserta yaitu nilai rata-rata pra siklus 59,4 (47\%), siklus I menunjukkan rata-rata sebesar 68,8 (59\%) dan siklus II sebesar 84,1 (88\%). Adanya peningkatan hasil belajar peserta didik setelah diterapkannya model pembelajaran NHT sebesar 24,7 (41\%).

Kata Kunci : Hasil belajar; Number Head Together; PKn 


\section{PENDAHULUAN}

Pendidikan Kewarganegaraan (PKn) adalah mata pelajaran yang memfokuskan pada pembentukan diri yang beragam dari segi agama, sosio-kultural, usia dan suku bangsa untuk menjadi warga Negara Indonesia yang cerdas, terampil dan berkarakter yang dilandasi oleh Pancasila dan UUD 1945 (Winataputra, 2011: 7). Depdiknas (2003: 4) membagi mata pelajaran PKn memiliki tiga dimensi, yaitu: 1) dimensi pengetahuan kewarganegaraan (Civics Knowledge) mencakup bidang politik, hukum dan moral; 2) dimensi keterampilan kewarganegaraan (Civics Skills) mencakup keterampilan partisipasi dalam kehidupan berbangsa dan bernegara; 3) dimensi nilai-nilai kewarganegaraan (Civics Values) mencakup percaya diri, penguasaan atas nilai religius, norma dan moral luhur.

Ketiga dimensi tersebut harus dikuasai dan ditanamkan kepada peserta didik sejak dini, karena dengan berkembangnya teknologi semakin mengikis nilai budaya dan nasionalisme generasi bangsa (Amboro, 2015). Hal ini didukung dengan penelitian Amrah (2016) bahwasanya generasi muda saat ini kurang apresiasi terhadap kebudayaan Indonesia, dan gaya hidup serta pola hidup yang meniru budaya asing. Sehingga untuk mengatasi masalah tersebut, perlu adanya edukasi terhadap generasi muda Indonesia, salah satunya adalah dengan pemahaman nilai dan makna dari sumpah pemuda. Menurut penelitian Muhtarom \& Erlangga (2021) nilai-nilai sumpah pemuda dapat membentuk karakter rasa nasionalisme generasi muda. Peristiwa dari sumpah pemuda mengandung nilai-nilai yang sejalan dengan karakter yang ada dalam kurikulum 2013 (Setiawan \& Hadi, 2018).

Melihat begitu krusialnya pemahaman nilai kewarganegaraan, sehingga mata pelajaran PKn tidak lepas dari kurikulum mulai dari Sekolah Dasar (SD) hingga perguruan tinggi. Dalam kurikulum SD, mata pelajaran PKn kelas III, Standar Kompetensi (SK) Mengamalkan makna sumpah pemuda memang sarat akan materi karena cakupannya luas dan perlu pemahaman. Berdasarkan hasil observasi dan dokumentasi di SDN 2 Pasarbanggi, hasil ulangan harian dan tes formatif Kompetensi Dasar (KD) mengenal makna satu nusa, satu bangsa dan satu bahasa, sebagian besar hasil belajar peserta didik masih di bawah Kriteria Ketuntasan Minimal (KKM), yaitu 65. Hasil analisis nilai ulangan harian pada prasiklus adalah nilai rata-rata sebesar 59,4, nilai tertinggi sebesar 80 dan nilai terendah sebesar 30, dengan persentase ketuntasan sebesar $47 \%$.

Berdasarkan hasil observasi, rendahnya hasil belajar peserta didik disebabkan karena pembelajaran yang membosankan dan berpusat pada guru, sehingga peserta didik menjadi tidak 
Jenius: Jurnal of Education Policy and Elementary Education Issues

Vol.1, No.2, Desember 2020, pp. 74-82

aktif. Hal ini didukung menurut Ramdhani (2014) pembelajaran yang berpusat pada guru menyebabkan peserta didik merasa bosan dan ilmu yang didapat pesert didik tidak berkembang, sedangkan menurut Suteja \& Cirebon (2017) pembelajaran yang berpusat pada peserta didik hanya menenkankan pada ilmu tanpa mengintegrasikan kognitif, afektif dan psikomotorik peserta didik.

Bertumpu pada kenyataan tersebut, untuk merangsang dan meningkatkan peran aktif peserta didik, baik secara individual dan kelompok dalam pembelajaran PKn, maka masalah tersebut harus ditangani dengan mencari model pembelajaran yang tepat dan sesuai dengan materi yang diajarkan. Guru sebagai pengajar dan fasilitator harus mampu melakukan pembelajaran yang menyenangkan dan menggairahkan, sehingga akan diperoleh hasil yang maksimal. Hal tersebut disebut dengan keterampilan atau kemampuan guru mengajar yang merupakan puncak keahlian guru yang professional.

Untuk mengaktifkan peserta didik di kelas, maka diperlukan model pembelajaran yang interaktif dan menyenangkan, sehingga peserta didik menjadi tidak bosan. Tileston (2007) memaparkan bahwa model pembelajaran NHT (Number Head Together) dapat mengaktifkan peserta didik dalam pembelajaran. Penerapan NHT yaitu dengan setiap peserta didik diberikan nomor (number) dalam kelompok. Guru memberikan pertanyaan dengan batas waktu tertentu untuk dijawab oleh peserta didik dan dikerjakan secara berkelompok. Peserta didik yang nomornya dipanggil oleh guru akan mewakili kelompok dalam menjawab pertanyaan. Model pembelajaran NHT selain mengaktifkan peserta didik, akan meningkatkan proses berpikir peserta didik. Hal ini sejalan dengan penelitian Wati \& Fatimah (2016), bahwasanya NHT dapat meningkatkan keterampilan berpikir kritis peserta didik. Berdasarkan penelitian Mulyana, Hanifah \& Jayadinata (2016) NHT dapat meningkatkan hasil belajar peserta didik. Menurut Hamdani (2011) kelebihan NHT adalah peserta didik dapat saling berdiskusi, peserta didik yang pandai dapat mengajari peserta didik yang kurang pandai. Berdasarkan latar belakang masalah yang dihadapi di SDN 2 Pasarbanggi, maka peneliti tertarik untuk menerapkan model pembelajaran NHT pada matapelajaran PKn untuk dapat meningkatkan hasil belajar peserta didik.

\section{METODE}

Jenis penelitian ini merupakan Penelitian Tindakan Kelas (PTK) yang berlangsung dalam dua siklus dan setiap siklus terdiri dari dua pertemuan. Tindakan dalam penelitian ini dengan menerapkan model pembelajaran kooperatif tipe NHT. Penelitian berlangsung di SDN 2 Pasarbanggi pada bulan Agustus sampai September tahun 2018 yang bertepatan dengan periode 
Jenius: Jurnal of Education Policy and Elementary Education Issues

Vol.1, No.2, Desember 2020, pp. 74-82

awal Semester I Tahun Pelajaran 2018/2019. Subyek penelitian melibatkan peserta didik kelas III sebanyak 17. Sedangkan obyek penelitian ini adalah hasil belajar PKn Materi Mengamalkan Makna Nilai-Nilai Sumpah Pemuda. Teknik pengumpulan data dilakukan dengan teknik tes dan teknik non tes. Teknik tes menggunakan butir soal, sedangkan teknik non tes menggunakan observasi dan dokumentasi. Alat pengumpulan data penelitian ini adalah soal ulangan dan lembar observasi. Data penelitian ini adalah aktivitas dan hasil belajar peserta didik sesuai dengan tindakan dalam pembelajaran. Aktivitas belajar berupa data kualitatif, sedangkan hasil belajar berupa data kuantitatif.

\section{HASIL DAN PEMBAHASAN}

Hasil belajar pada Prasiklus termasuk rendah. Sesuai dengan analisis nilai ulangan harian diketahui nilai rata-rata sebesar 59,4, nilai tertinggi sebesar 80 dan nilai terendah sebesar 30 . Persentase ketuntasan sebesar 47\%. Hasil belajar secara lengkap dalam graifk berdasar penilaian 17 peserta didik dijabarkan sebagai berikut:

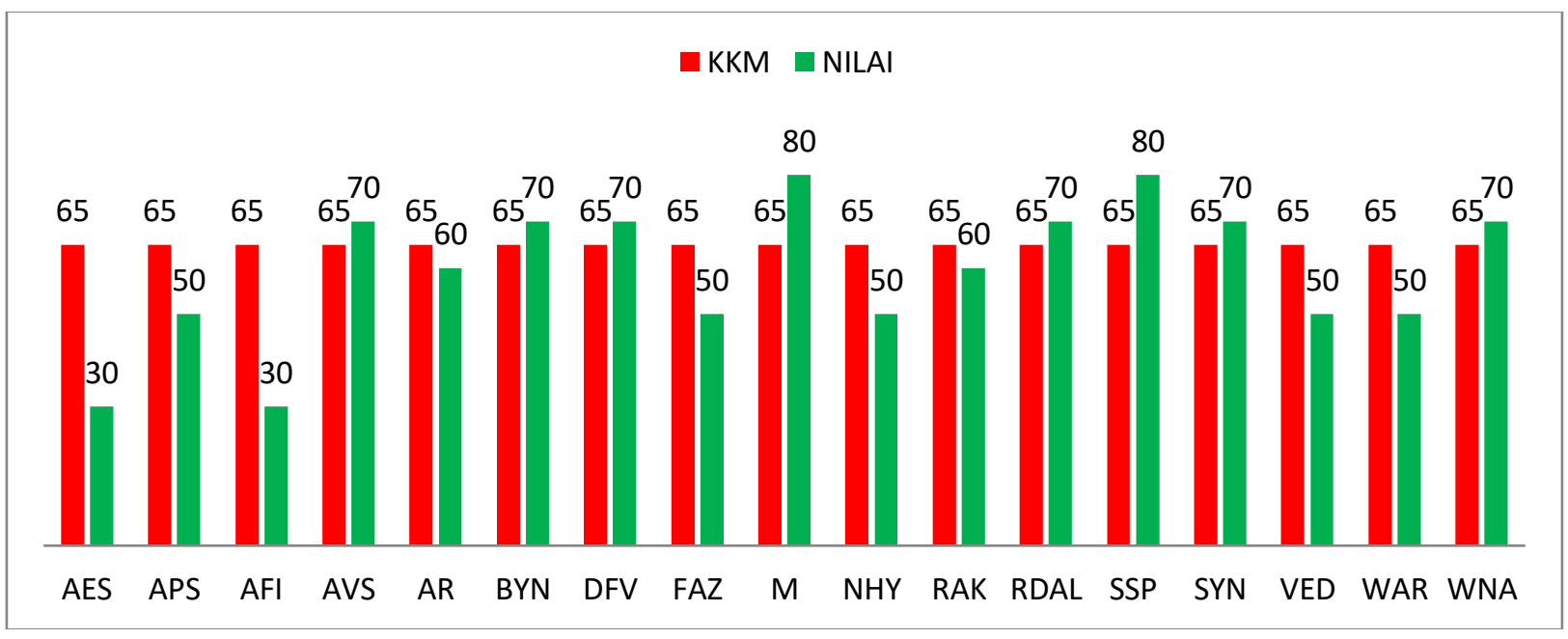

Grafik 1. Hasil belajar pada Prasiklus.

Pembelajaran pada Siklus I, peserta didik dibagi menjadi 3 kelompok, masing-masing terdiri dari 5-6 anggota, yaitu 1 kelompok terdiri dari 5 anggota dan 2 kelompok terdiri dari 6 anggota. Sesuai dengan tindakan dalam pembelajaran, masing-masing anggota kelompok memakai nomor kepala. Masing-masing anggota menentukan sendiri nomor kepala sesuai petunjuk dari guru bahwa nomor awal adalah peserta didik yang kurang cerdas, begitu seterusnya nomor akhir adalah peserta didik yang paling cerdas. Sesuai dengan tindakan dalam pembelajaran, aktivitas 
Jenius: Jurnal of Education Policy and Elementary Education Issues

Vol.1, No.2, Desember 2020, pp. 74-82

belajar peserta didik semakin aktif, berani bertanya dan tidak bermain dengan temannya. Selama proses pembelajaran berlangsung, pembelajaran semakin kondusif dan sesuai dengan rencana. Setelah dilakukan evaluasi, didapatkan nilai hasil beljar dengan rata-rata sebesar 68,8, nilai tertinggi sebesar 100 dan nilai terendah sebesar 50. Setelah dilakukan persentase diperoleh hasil ketuntasan sebesar 59\%. Hasil belajar secara lengkap dalam grafik sebagai berikut:

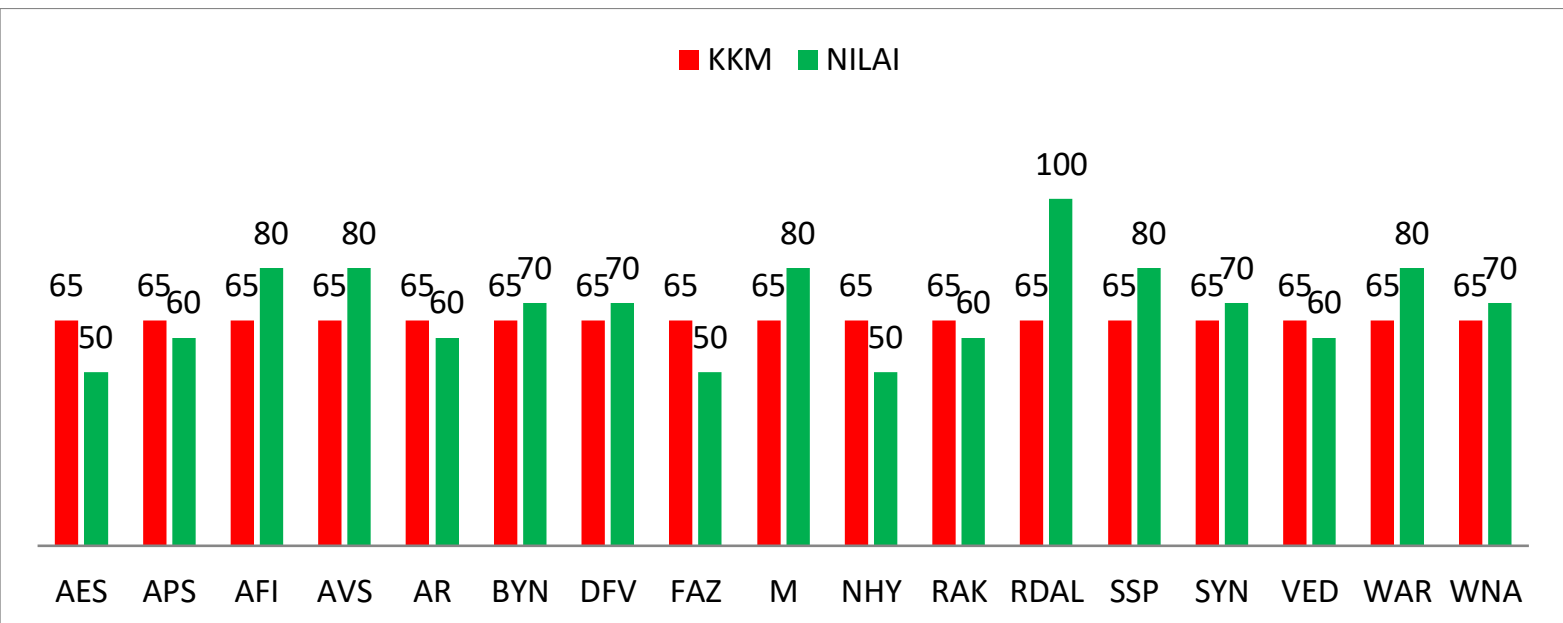

Grafik 2. Hasil belajar pada Siklus I.

Pembelajaran pada Siklus II merupakan kelanjutan dan pembaruan dari pembelajaran sebelumnya pada Siklus I. Peserta didik masih dibagi menjadi 3 kelompok dengan komposisi yang sama (berkemampuan tinggi, sedang, dan kurang), sehingga tidak ada perubahan dalam masingmasing kelompok tersebut. Yang membedakan pembelajaran pada Siklus I dan Siklus II adalah penomoran, yaitu penentuan nomor kepala bagi anggota (peserta didik dengan kemampuan yang sama pada kelompok yang berbeda diberikan nomor yang sama) untuk menyeimbangkan kemampuan berpikir antar kelompok.

Pada Siklus II, guru yang menentukan nomor kepala bagi masing-masing anggota. Penomoran sesuai dengan aktivitas dan hasil belajar, sehingga anggota yang menjadi wakil kelompok cenderung seimbang. Demikian halnya dengan berpikir bersama, durasi menjadi lebih lama daripada sebelumnya. Sesuai dengan tindakan dalam pembelajaran, aktivitas belajar peserta didik semakin aktif, berani bertanya dan tidak bermain dengan temannya serta berani mengemukakan pendapat, sehingga pembelajaran semakin kondusif dan sesuai dengan rencana. Setelah dilakukan evaluasi, didapatkan nilai hasil belajar dengan rata-rata sebesar 84,1, nilai tertinggi sebesar 100 dan nilai terendah sebesar 60, dan menunjukkan persentase ketuntasan 
sebesar $88 \%$. Sesuai dengan tindakan dalam pembelajaran, terjadinya peningkatan hasil belajar peserta didik. Hal tersebut sesuai dengan aktivitas belajar peserta didik yang semakin aktif dan pembelajaran yang semakin kondusif. Hasil belajar pada siklus II secara lengkap dijelaskan dalam graifk sebagai berikut:

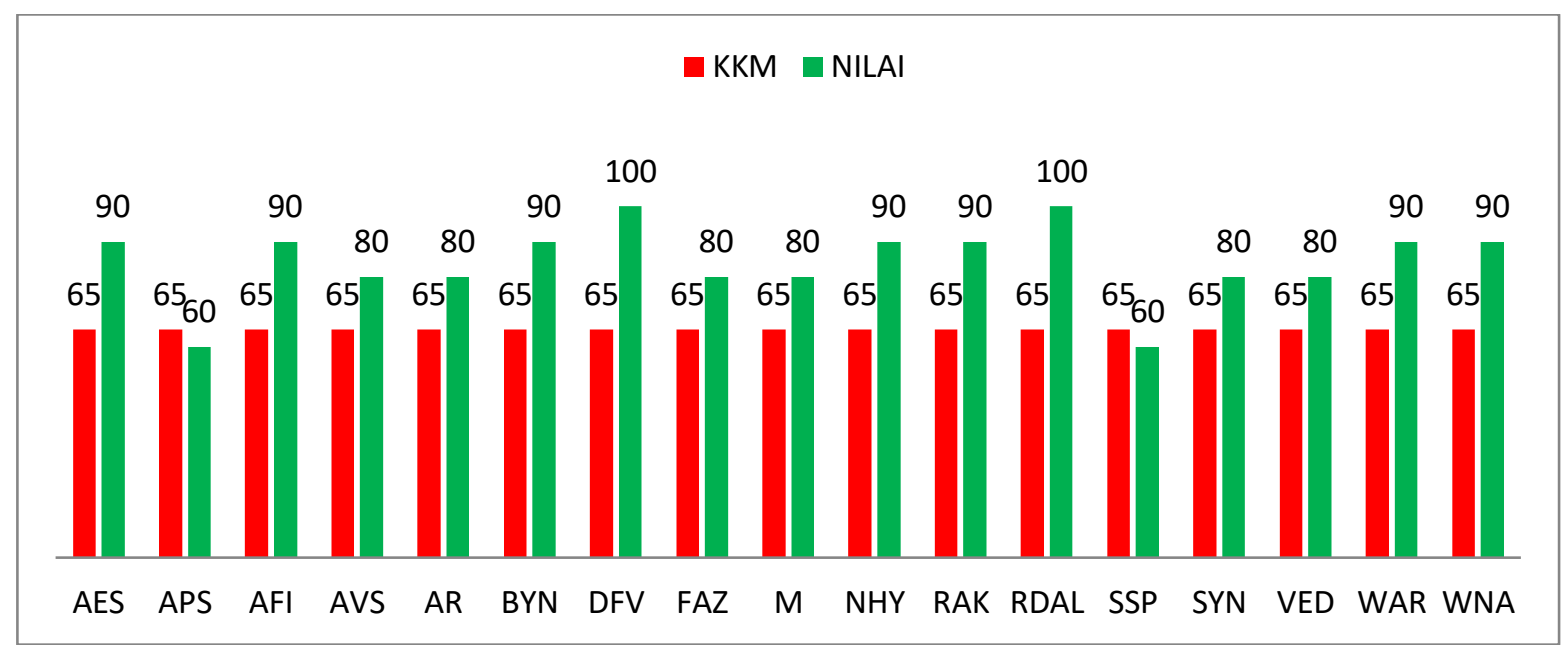

Grafik 3. Hasil belajar pada Siklus II.

Pada Siklus I, peserta didik yang menentukan sendiri nomor kepala, sehingga kecerdasan masing-masing anggota antar kelompok kurang seimbang, dan kurangnya kerjasama antar anggota kelompok. Sedangkan pada Siklus II, guru yang menentukan nomor kepala (sesuai kemampuan peserta didik), sehingga kecerdasan masing-masing anggota antar kelompok cenderung seimbang, kerjasama antar anggota kelompok juga terlihat semakin baik. Bahkan durasi berpikir dalam kelompok sesuai dengan tugas lebih lama pada Siklus II daripada Siklus I.

Hasil belajar pada prasiklus termasuk rendah. Hal tersebut sesuai dengan nilai rata-rata yang lebih rendah daripada KKM dan persentase ketuntasan lebih rendah daripada 75\%. Sesuai dengan tindakan dalam pembelajaran, hasil belajar pada Siklus I mengalami peningkatan. Nilai rata-rata lebih tinggi daripada KKM, namun persentase ketuntasan lebih rendah daripada $75 \%$. Sedangkan hasil belajar pada Siklus II mengalami peningkatan yang semakin optimal. Nilai ratarata lebih tinggi daripada KKM dan persentase ketuntasan lebih tinggi daripada 75\%. Analisis hasil belajar pada Prasiklus, Siklus I dan Siklus II secara lengkap pada grafik dan tabel sebagai berikut: 


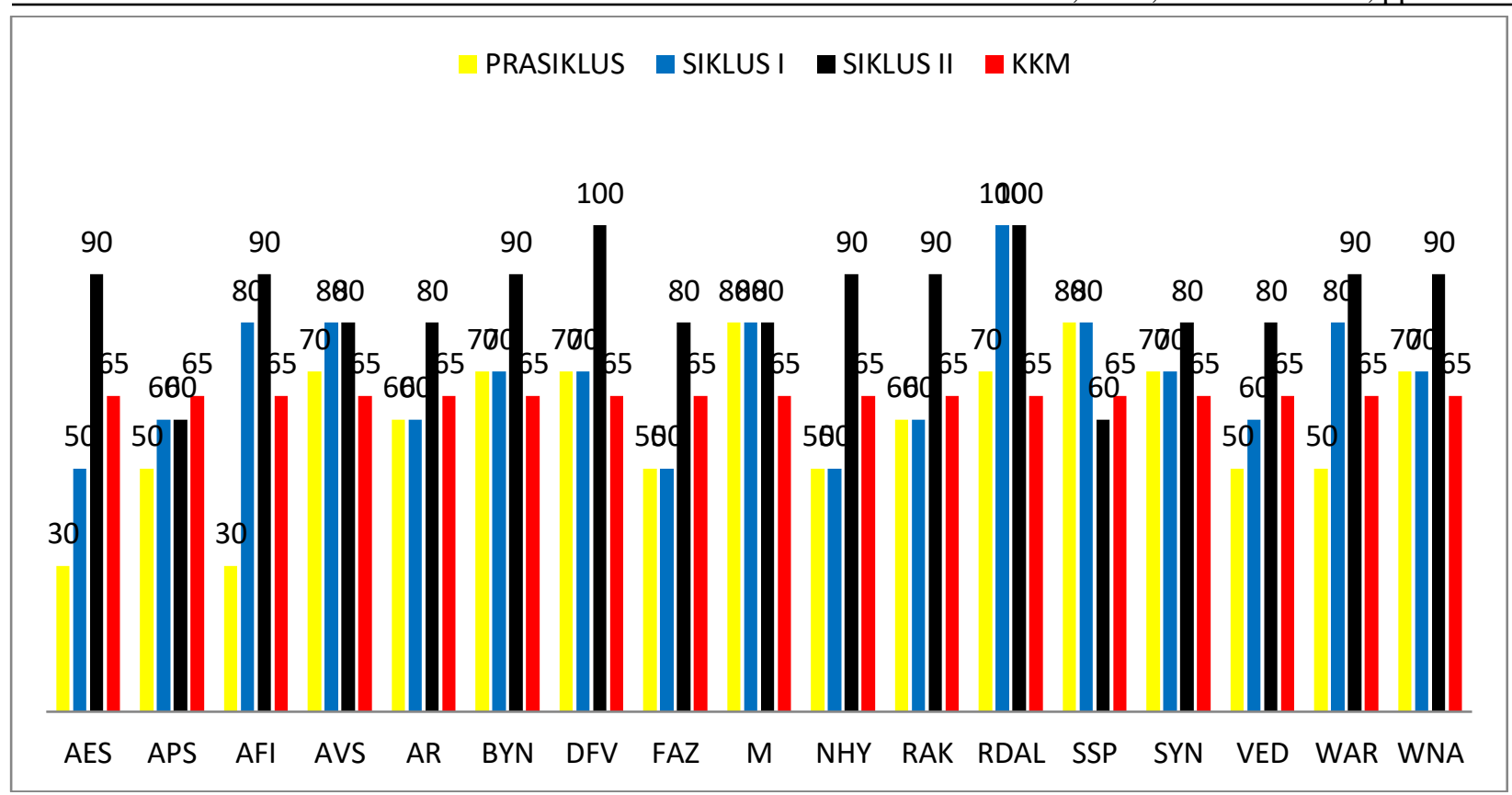

Grafik 4. Hasil belajar pada Prasiklus, Siklus I dan Siklus II.

Tabel 1. Analisis hasil belajar pada Prasiklus, Siklus I dan Siklus II.

\begin{tabular}{clccc}
\hline No & \multicolumn{1}{c}{ Hasil Belajar } & Prasiklus & Siklus I & Siklus II \\
\hline 1 & Nilai rata-rata & $59,4<65$ & $68,8>65$ & $84,1>65$ \\
2 & Nilai tertinggi & 80 & 100 & 100 \\
3 & Nilai terendah & 30 & 50 & 60 \\
4 & Persentase ketuntasan & $47 \%<75 \%$ & $59 \%<75 \%$ & $88 \%>75 \%$ \\
\hline
\end{tabular}

Berdasarkan hasil analisis hasil belajar mulai dari prasiklus yang menerapkan pembelajaran konvensional, serta siklus pertama dan kedua yang menerapkan model pembelajaran NHT, terdapat adanya peningkatan hasil belajar peserta didik, hal ini dikarenakan peserta didik aktif berpikir dan bekerjasama untuk mencari jawaban berdasar permasalahan yang diajukan guru. Hal ini sejalan berdasar penelitian Wijayati, Kusumawati \& Kushandayani (2008) bahwasanya model pembelajaran NHT lebih efektif dalam merangsang berpikir peserta didik sehingga meningkatkan hasil belajar peserta didik daripada pembelajaran yang konvensional. Selain itu, model pembelajaran NHT dapat meningkatkan pemahaman karena merangsang keaktifan peserta didik (Alie, 2013; Juliartini \& Arini, 2017; Permana, 2016).

Menurut Wijayati, Kusumawati \& Kushandayani (2008) yang menunjang keberhasilan model pembelajaran NHT adalah heterogennya pembagian peserta didik dalam satu kelompok (berkemampuan tinggi, sedang, dan rendah). Menurut Esminarto, Sukowati, Suryowati \& Anam (2016) pembagian kelompok secara heterogen untuk memastikan anggota kelompok dapat belajar 
Jenius: Jurnal of Education Policy and Elementary Education Issues

Vol.1, No.2, Desember 2020, pp. 74-82

dengan baik, dan mencegah ketergantungan anggota kelompok dalam menyelesaikan tugas dan merangsang rasa percaya diri peserta didik. Sedangkan menurut Agustina, Saputro \& Mulyani (2013) pembagian kelompok secara heterogen dapat memungkinkan peserta didik yang memiliki kemampuan akademik tinggi membantu memahamkan temannya yang kurang mengerti.

\section{KESIMPULAN DAN SARAN}

\section{Simpulan}

Berdasar hasil penelitian dan pembahasan, maka dapat ditarik kesimpulan dalam penelitian ini yaitu hasil belajar PKn materi mengamalkan makna nilai-nilai sumpah pemuda pada peserta didik Kelas III SDN 2 Pasarbanggi meningkat dari prasiklus (sebelum diterapkannya model pembelajaran NHT) sampai setelah diterapkannya model pembelajaran NHT dari siklus I dan II. Terjadinya peningkatan dari pra siklus sampai setelah diterapkannya model pembelajaran NHT pada sikus II sebesar 41\%. Meningkatnya hasil belajar dengan diterapkannya model pembelajaran NHT dipengaruhi oleh faktor kerjasama antar anggota kelompok, keaktifan peserta didik karena pembelajaran yang merangsang interaksi antar anggota kelompok untuk berpikir, dan heterogennya anggota dalam kelompok (berkemampuan tinggi, sedang, dan kurang).

\section{DAFTAR PUSTAKA}

Agustina, E., Saputro, A. N. C., \& Mulyani, S. (2013). Penggunaan metode pembelajaran jigsaw berbantuan handout untuk meningkatkan aktivitas dan prestasi belajar peserta didik pada materi pokok hidrokarbon kelas XC SMA negeri 1 Gubug tahun ajaran 2012/2013. Jurnal Pendidikan Kimia, 2(4), 66-71.

Alie, N. H. (2013). Penggunaan model pembelajaran kooperatif tipe NHT untuk meningkatkan hasil belajar peserta didik kelas X2 SMA Neg. 3 Gorontalo pada materi jarak pada bangun ruang. Jurnal Entropi, 8(01).

Amboro, K. (2015). Membangun kesadaran berawal dari pemahaman: Relasi pemahaman sejarah dengan kesadaran sejarah mahapeserta didik program studi pendidikan sejarah fkip universitas muhammadiyah metro. Jurnal Historia, 3(2). 2

Amrah, A. (2016). Mengulik pengembangan nasionalisme generasi muda di era globalisasi. Publikasi Pendidikan, 6(2).

Departemen Pendidikan Nasional (Depdiknas). (2003). Petunjuk teknis penyelenggaraan mata pelajaran pendidikan kewarganegaraan. Jakarta: Depdiknas.

Esminarto, E., Sukowati, S., Suryowati, N., \& Anam, K. (2016). Implementasi model STAD dalam meningkatkan hasil belajar siwa. BRILIANT: Jurnal Riset dan Konseptual, 1(1), 16-23.

Hamdani (2011). Strategi belajar mengajar. Bandung: Pustaka Setia.

Juliartini, N. M., \& Arini, N. W. (2017). Penerapan model pembelajaran nht untuk meningkatkan hasil belajar ipa peserta didik kelas III. Journal of Education Action Research, 1(3), 240-250.

Muhtarom, H., \& Erlangga, G. (2021). Peran nilai-nilai sumpah pemuda dalam membentuk karakter 
peserta didik di SMAN 18 Jakarta. Criksetra: Jurnal Pendidikan Sejarah, 10(2), 114-128.

Mulyana, M. A., Hanifah, N., \& Jayadinata, A. K. (2016). Penerapan model kooperatif tipe numbered heads together (NHT) untuk meningkatkan hasil belajar peserta didik pada materi kenampakan alam dan sosial budaya. Jurnal Pena Ilmiah, 1(1), 331-340.

Permana, E. P. (2016). Penerapan metode pembelajaran kooperatif numbered heads together (NHT) untuk meningkatkan hasil belajar dan berpikir kritis peserta didik pada mata pelajaran IPS SD. Jurnal Pendidikan Dasar Nusantara, 1(2).

Ramdhani, M. A. (2014). Perbandingan strategi pembelajaran teacher centered learning dengan student centered learning terhadap hasil belajar pada mata pelajaran tarikh peserta didik kelas VIII SMP Muhammadiyah 4 Surakarta (Doctoral dissertation, Universitas Muhammadiyah Surakarta).

Setiawan, J., \& Hadi, R. S. (2018). Nilai-nilai pendidikan karakter dalam materi sejarah kebangkitan nasional. Jurnal Sejarah Dan Budaya, 12(1), 39-48. http:/ / dx.doi.org/10.17977/um020v12i12017p39

Suteja, J., \& Cirebon, I. S. N. (2017). Model-model pembelajaran dalam kurikulum berbasis kompetensi kkni di perguruan tinggi. Jurnal Edueksos, 6(1), 81-100.

Tileston, D.W. (2007). Teaching startegies for active learning. California: corwin press

Wati, W., \& Fatimah, R. (2016). Effect size model pembelajaran kooperatif tipe numbered heads together (NHT) terhadap kemampuan berpikir kritis peserta didik pada pembelajaran fisika. Jurnal Ilmiah Pendidikan Fisika Al-Biruni, 5(2), 213-222.

Wijayati, N., Kusumawati, I., \& Kushandayani, T. (2008). Penggunaan model pembelajaran numbered heads together untuk meningkatkan hasil belajar kimia. Jurnal Inovasi Pendidikan Kimia, 2(2).

Winataputra, U. (2011). Pembelajaran PKn di SD. Jakarta: Universitas Terbuka Press. 